Review Article

DOI: $10.36959 / 719 / 576$

\title{
Clinical Aspects of COVID-19 in Patients with Solid Organ Transplantation: A Systematic Review
}

\author{
René Hage ${ }^{1,2^{*}}$, Carolin Steinack $k^{1,2}$ and Macé M Schuurmans ${ }^{1,2}$ \\ ${ }^{1}$ Division of Pulmonology, University Hospital Zurich, Switzerland \\ ${ }^{2}$ Faculty of Medicine, University of Zurich, Switzerland
}

\begin{abstract}
Background: Coronavirus disease 19 (COVID-19), is an infectious disease caused by the Severe Acute Respiratory Syndrome Coronavirus 2 (SARS-CoV-2). This virus is causing a pandemic with more than 40 million proven infections worldwide.
\end{abstract}

Aim: In order to summarize the clinical characteristics of coronavirus disease-19 (COVID-19) in solid organ transplant (SOT) recipients, we conducted a systematic review of studies on COVID-19 in these patients.

\begin{abstract}
Methods: The literature search was conducted repeatedly between March 16th and May 1st, 2020. We searched original papers, observational studies, case reports, and meta-analyses published between December 2019 and May 1st 2020 using two databases (PubMed, Google Scholar) with the search terms: [transplant OR immune suppression] AND [COVID-19 OR SARS-CoV-2]. Further inclusion criteria were publications in English, French, German and Italian and reference to humans. We also searched the reference lists of the studies encountered. Studies on non-solid organ transplantation were excluded, as well as animal and in vitro studies.

Results: From an initial search 37 potential articles were retrieved, of which 15 were excluded after full-text screening (not being case reports or case series), leaving 22 studies for inclusion. No further studies were identified from the bibliographies of the retrieved articles.

Conclusion: Between March 16th and May 1st, 2020, only 49 SOT recipients have been described in literature. Most of these patients survived, and had a fairly mild disease course. Based on the limited research data, no firm conclusions can be made concerning specific treatment of SOT recipients, but the current evidence suggests that immunosuppression, especially the calcineurin inhibitors, decreases the incidence and improves the outcome of symptomatic COVID-19, by preventing hyperinflammation (cytokine storm). Evidence based guidelines are urgently needed for this particular group of patients.
\end{abstract}

\section{Keywords}

SARS-CoV-2, Coronavirus, Immunosuppression, Tacrolimus, Cyclosporine A, Calcineurin inhibitor, Corticosteroids, Mycophenolate mofetil, Hyperinflammation, Cytokine storm, Transplantation

\section{Introduction}

Community-acquired respiratory viruses (CARVs) cause upper and/or lower respiratory tract disease after solid organ transplant (SOT) and are related to high morbidity and mortality in SOT recipients. The most frequent CARVs are human parainfluenza virus (PIV), metapneumovirus (MPV), rhino-/ enterovirus (REV), respiratory syncytial virus (RSV), influenza virus (IV) and coronaviruses (CoVs). To date, 7 human CoVs have been identified. The $4 \mathrm{CoV}$ species with a fairly benign outcome are called 229E, OC43, NL63 and HKU1 and in immunocompetent people generally cause mild respiratory or gastrointestinal symptoms. The 3 highly dangerous CoV species, associated with outbreaks with a high morbidity and mortality, are the Severe Acute Respiratory Syndrome Coronavirus (SARS-CoV), the Middle East Respiratory Syndrome Corona- virus (MERS-CoV) and the recent coronavirus SARS-CoV-2. The disease caused by infection with SARS-CoV-2 is called COVID-19.

*Corresponding author: René Hage, Division of Pulmonology, University Hospital Zurich, Raemistrasse 100, 8091 Zurich, Switzerland; Faculty of Medicine, University of Zurich, Raemistrasse 71, 8006 Zurich, Switzerland, Tele: +41-44-255-22-21, Fax: +4144-255-44-51

Accepted: November 24, 2020

Published online: November 26, 2020

Citation: Hage R, Steinack C, Schuurmans MM (2020) Clinical Aspects of COVID-19 in Patients with Solid Organ Transplantation: A Systematic Review. Res Rev Infect Dis 3(2):102-114 
The aim of this review is to summarize the clinical characteristics in SOT recipients, as has been reported in the medical literature. Among these clinical characteristics, we summarized the type of organ transplantation (heart, lung, liver, kidney), age, sex, type of immunosuppressive therapy, symptoms at presentation, temperature, oxygen saturation $\left(\mathrm{SpO}_{2}\right)$, C-reactive protein (CRP) level, chest computed tomography (CT), severity of COVID-19 (Siddiqi stage), treatment and outcome. These findings are presented in a table.

\section{Methods}

The literature search was conducted repeatedly between March 16th and May 1st, 2020. We searched original papers, observational studies, case reports, and meta-analyses published between 2019 and 2020 using two databases (PubMed, Google Scholar) with the search terms: [transplant OR immunosuppression] AND [COVID-19 OR SARS-CoV-2]. Further inclusion criteria were publications in English, French, German and Italian and reference to humans. We also searched the reference lists of the studies encountered. Exclusion criteria were non-solid organ transplantation, animal and in vitro studies. Reviews were excluded as well. A panel of two clinicians (two pulmonary physicians, R.H. and M.M.S.) conducted the literature search, and three clinicians (pulmonary physicians, R.H., C.S. and M.M.S.) reached consensus on the articles that were included in this review, based on the previously described in- and exclusion criteria.

\section{Results}

From an initial search 37 potential articles were retrieved, of which 15 were excluded after full-text screening (not being case reports or case series), leaving 22 studies for inclusion (Table 1). No further studies were identified from the bibliographies of retrieved articles. The results of the studies are summarized in Table 1. There were three studies describing patients with a heart transplantation (including 3 patients), one study with a combined heart and kidney transplantation (1 patient), 12 with a kidney transplantation (35 patients), 5 with a liver transplantation (5 patients) and 4 with a lung transplantation (5 patients).

The distribution of age, sex and the immunosuppressive therapy are shown in Table 1. Symptoms at presentation included constitutional (fatigue, fever, chills, confusion), respiratory (cough, chest tightness, dyspnea) and gastrointestinal symptoms (diarrhea, nausea, vomiting, severe abdominal

Table 1: Key features of main references of original papers and case reports (excluding reviews, meta-analyses or commentaries).

\begin{tabular}{|c|c|c|c|c|c|c|c|c|}
\hline $\begin{array}{l}\text { Author, } \\
\text { ref. and } \\
\text { date }\end{array}$ & $\begin{array}{l}\text { Solid or- } \\
\text { gan year } \\
\text { of trans- } \\
\text { plant }\end{array}$ & $\begin{array}{l}\text { Age (y) } \\
\text { Sex } \\
(m / f)\end{array}$ & IST & $\begin{array}{l}\text { Symptoms at pre- } \\
\text { sentation }\end{array}$ & $\begin{array}{l}\text { Temp } \\
\mathrm{SpO}_{2} \\
\text { CRP } \\
\text { CT chest }\end{array}$ & $\begin{array}{l}\text { Severity } \\
\text { Stage (Sid- } \\
\text { diqi) }\end{array}$ & Treatment & Outcome \\
\hline $\begin{array}{l}\text { Li F, et al. } \\
{[47]}\end{array}$ & $\begin{array}{l}\text { Heart, } \\
2003\end{array}$ & $51, m$ & $\begin{array}{l}\text { Tac } \\
\text { MMF }\end{array}$ & $\begin{array}{l}\text { intermittent fever } \\
\text { chills } \\
\text { fatigue } \\
\text { poor } \\
\text { appetite } \\
\text { diarrhea }\end{array}$ & $\begin{array}{l}38.5 \\
99 \%-->75 \% \\
18.6 \mathrm{mg} / \mathrm{L} \\
\text { GGO (bilat.) }\end{array}$ & $\| \mathrm{A}-->$ IIB & $\begin{array}{l}\text { levofloxacin iv } \\
\text { ribavirin iv } \\
\text { moxifloxacin iv } \\
\text { ganciclovir iv } \\
\text { IVIG } \\
\text { methylprednisolone iv } \\
\text { moxifloxacin po } \\
\text { umifenovir } \\
\text { Tac and MMF stopped } \\
\text { from day 7-13 }\end{array}$ & $\begin{array}{l}\text { survived, hos- } \\
\text { pitalization } \\
27 \text { days, no } \\
\text { mechanical } \\
\text { ventilation or } \\
\text { ECMO, CT at } \\
\text { discharge im- } \\
\text { proved (resid- } \\
\text { ual lesions). }\end{array}$ \\
\hline $\begin{array}{l}\text { Li F, et al. } \\
{[47]}\end{array}$ & $\begin{array}{l}\text { Heart, } \\
2017\end{array}$ & $43, m$ & $\begin{array}{l}\text { Tac } \\
\text { MMF }\end{array}$ & $\begin{array}{l}\text { fever ( } 2 \text { days) } \\
\text { fatigue } \\
\text { poor } \\
\text { appetite }\end{array}$ & $\begin{array}{l}38.5 \\
\text { normal } \mathrm{SpO}_{2} ? \\
13.4 \mathrm{mg} / \mathrm{L} \\
\text { GGO (bilat.) }\end{array}$ & IIA & $\begin{array}{l}\text { ceftriaxone iv } \\
\text { ganciclovir iv } \\
\text { moxifloxacin po } \\
\text { arbidol po }\end{array}$ & $\begin{array}{l}\text { survived, hos- } \\
\text { pitalization } \\
11 \text { days, no } \\
\text { mechanical } \\
\text { ventilation or } \\
\text { ECMO }\end{array}$ \\
\hline $\begin{array}{l}\text { Kates O, et } \\
\text { al. [48] }\end{array}$ & $\begin{array}{l}\text { Heart, } \\
1997\end{array}$ & $74, m$ & $\begin{array}{l}\text { Tac } \\
\text { Mes }\end{array}$ & $\begin{array}{l}\text { sore throat } \\
\text { dry cough }\end{array}$ & $\begin{array}{l}40, \\
\mathrm{SpO}_{2} \text { and } \mathrm{CRP} \\
\text { unknown } \\
\text { CXR normal }\end{array}$ & I & $\begin{array}{l}\text { immunosuppression } \\
\text { unchanged }\end{array}$ & $\begin{array}{l}\text { survived } \\
\text { no hospitaliza- } \\
\text { tion }\end{array}$ \\
\hline
\end{tabular}


Citation: Hage R, Steinack C, Schuurmans MM (2020) Clinical Aspects of COVID-19 in Patients with Solid Organ Transplantation: A Systematic Review. Res Rev Infect Dis 3(2):102-114

\begin{tabular}{|c|c|c|c|c|c|c|c|c|}
\hline $\begin{array}{l}\text { Hsu JJ, et } \\
\text { al. [15] }\end{array}$ & $\begin{array}{l}\text { Heart and } \\
\text { Kidney, } \\
2017\end{array}$ & $39, m$ & $\begin{array}{l}\text { Tac } \\
\text { MMF } \\
\text { Pred }\end{array}$ & $\begin{array}{l}\text { fever } \\
\text { headache } \\
\text { sore throat } \\
\text { dry cough } \\
\text { dyspnea } \\
\text { fatigue } \\
\text { myalgias }\end{array}$ & $\begin{array}{l}38.8 \\
97 \% \\
67 \mathrm{mg} / \mathrm{L} \\
\text { CXR mild con- } \\
\text { gestion }\end{array}$ & | --> ||B & $\begin{array}{l}\text { Tac unchaged } \\
\text { MMF stopped } \\
\text { Pred continued }\end{array}$ & $\begin{array}{l}\text { survived, hos- } \\
\text { pitalization } 15 \\
\text { days }\end{array}$ \\
\hline $\begin{array}{l}\text { Zhu L, et al. } \\
\text { [49] }\end{array}$ & $\begin{array}{l}\text { Kidney, } \\
2008\end{array}$ & $52, \mathrm{~m}$ & $\begin{array}{l}\text { Tac } \\
\text { MMF } \\
\text { Pred }\end{array}$ & $\begin{array}{l}\text { fatigue } \\
\text { dyspnea } \\
\text { chest pain tight- } \\
\text { ness } \\
\text { nausea } \\
\text { loss of } \\
\text { appetite } \\
\text { abdominal } \\
\text { pain } \\
\text { dry cough } \\
\text { fever } \\
\text { headache }\end{array}$ & $\begin{array}{l}38.9 \\
96 \% \\
30.2 \mathrm{mg} / \mathrm{L} \\
\text { GGO (bilat.) }\end{array}$ & IIA & $\begin{array}{l}\text { umifenovir } \\
\text { methylprednisolone } \\
\text { interferon- } \alpha \text { inh. } \\
\text { IVIG } \\
\text { biapenem } \\
\text { pantoprazole } \\
\\
\text { Tac stopped from day } \\
6-11 \text {, reintroduced with } \\
50 \% \text { reduction for } 7 \\
\text { days, followed by nor- } \\
\text { mal doses } \\
\text { MMF stopped from day } \\
6-11, \text { reintroduced by } \\
\text { normal dose after } 12 \\
\text { days } \\
\text { pred stopped during } \\
\text { hospitalization }\end{array}$ & $\begin{array}{l}\text { survived, hos- } \\
\text { pitalization } \\
12 \text { days, no } \\
\text { mechanical } \\
\text { ventilation or } \\
\text { ECMO }\end{array}$ \\
\hline $\begin{array}{l}\text { Guillen E, } \\
\text { et al. [50] }\end{array}$ & $\begin{array}{l}\text { Kidney, } \\
2016\end{array}$ & $50, m$ & $\begin{array}{l}\text { Tac } \\
\text { Everol } \\
\text { Pred }\end{array}$ & $\begin{array}{l}\text { fever } \\
\text { vomiting }\end{array}$ & $\begin{array}{l}37.4 \\
98 \% \\
13.2 \mathrm{ml} / \mathrm{L} \\
\text { unilateral --> } \\
\text { bilat. infiltrate }\end{array}$ & $\| A-->\mid I B$ & $\begin{array}{l}\text { ceftriaxone } \\
\text { azithromycin } \\
\text { lopinavir/ritonavir } \\
\text { HCQ } \\
\text { TAC and everol tem- } \\
\text { porary stopped due to } \\
\text { interactions }\end{array}$ & \\
\hline $\begin{array}{l}\text { Gandolfini } \\
\text { I, et al. [51] }\end{array}$ & $\begin{array}{l}\text { Kidney, } \\
2010\end{array}$ & $75, \mathrm{~m}$ & $\begin{array}{l}\text { Tac } \\
\text { Pred } \\
\text { MMF }\end{array}$ & $\begin{array}{l}\text { Fever } \\
\text { Cough } \\
\text { Myalgia } \\
\text { Dyspnea }\end{array}$ & $\begin{array}{l}38.0 \\
\mathrm{SpO}_{2} \text { and } \mathrm{CRP} \\
\text { unknown } \\
\text { GGO }\end{array}$ & IIB & $\begin{array}{l}\text { NIV } \\
\text { HCQ } \\
\text { Lopinavir-ritonavir or } \\
\text { darunavir-cobicistat }\end{array}$ & died \\
\hline $\begin{array}{l}\text { Gandolfini } \\
\text { I, et al. [51] }\end{array}$ & $\begin{array}{l}\text { Kidney, } \\
2019\end{array}$ & $52, f$ & $\begin{array}{l}\text { Tac } \\
\text { Pred } \\
\text { MMF }\end{array}$ & $\begin{array}{l}\text { Fever } \\
\text { Cough } \\
\text { Myalgia } \\
\text { Dyspnea }\end{array}$ & $\begin{array}{l}39.0 \\
\mathrm{SpO}_{2} \text { and } \mathrm{CRP} \\
\text { unknown } \\
\text { GGO }\end{array}$ & IIB & $\begin{array}{l}\text { NIV } \\
\text { HCQ } \\
\text { Lopinavir-ritonavir or } \\
\text { darunavir-cobicistat } \\
\text { Colchicine }\end{array}$ & alive \\
\hline
\end{tabular}


Citation: Hage R, Steinack C, Schuurmans MM (2020) Clinical Aspects of COVID-19 in Patients with Solid Organ Transplantation: A Systematic Review. Res Rev Infect Dis 3(2):102-114

\begin{tabular}{|c|c|c|c|c|c|c|c|c|}
\hline $\begin{array}{l}\text { Bartiromo } \\
\text { M, et al. } \\
{[28]}\end{array}$ & $\begin{array}{l}\text { Kidney, } \\
1993\end{array}$ & $36, f$ & $\begin{array}{l}\text { Tac } \\
\text { Pred }\end{array}$ & $\begin{array}{l}\text { Fatigue } \\
\text { Dry cough } \\
\text { Coryza }\end{array}$ & $\begin{array}{l}36.3 \\
\mathrm{SpO}_{2} 99 \% \\
\mathrm{CRP} 67 \\
\text { CXR infiltrates }\end{array}$ & IIA & $\begin{array}{l}\text { lopinavir/ritonavir, later } \\
\text { replaced by } \\
\text { darunavir/cobicistat } \\
\text { Tac unchanged, but de- } \\
\text { veloped extremely high } \\
\text { level, stopped after } \\
\text { discharge }\end{array}$ & $\begin{array}{l}\text { survived after } \\
9 \text { days hospi- } \\
\text { talization }\end{array}$ \\
\hline $\begin{array}{l}\text { Marx D, et } \\
\text { al. [52] }\end{array}$ & $\begin{array}{l}\text { Kidney, } \\
2017\end{array}$ & $58, m$ & $\begin{array}{l}\text { Bela } \\
\text { MMF } \\
\text { Pred }\end{array}$ & $\begin{array}{l}\text { Fever } \\
\text { Mild dyspnea } \\
\text { Cough }\end{array}$ & $\begin{array}{l}38 \\
\mathrm{SpO}_{2} 96 \% \\
\text { GGO }\end{array}$ & IIA & $\begin{array}{l}\text { Bela stop } \\
\text { MMF stop }\end{array}$ & $\begin{array}{l}\text { survived after } \\
16 \text { days hospi- } \\
\text { talization }\end{array}$ \\
\hline $\begin{array}{l}\text { Husain SA, } \\
\text { et al. [53] }\end{array}$ & $\begin{array}{l}\text { Kidney } \\
\text { Case Series } \\
n=15\end{array}$ & $\begin{array}{l}51(21- \\
78), 5 \mathrm{f} \\
10 \mathrm{~m}\end{array}$ & $\begin{array}{l}\text { Tac } \\
\text { MMF } \\
\text { Bela } \\
\text { Leflu } \\
\text { Aza } \\
\text { Pred }\end{array}$ & $\begin{array}{l}\text { Fever } \\
\text { Cough } \\
\text { Fatigue } \\
\text { Malaise } \\
\text { Dyspnea } \\
\text { Diarrhea } \\
\text { Myalgia } \\
\text { Hemoptysis } \\
\text { Emesis }\end{array}$ & $\begin{array}{l}\text { CXR bilateral } \\
\text { opacities ( } n \\
=7,47 \%), \text { no } \\
\text { acute findings } \\
(n=5,33 \%), \\
\text { lobar infiltrate } \\
(n=2,14 \%)\end{array}$ & & $\begin{array}{l}\text { Antimetabolites or } \\
\text { leflunomide stop ( } n= \\
10,71 \% \text { ) } \\
\text { Tac unchanged } \\
\text { Pred unchanged ( } n=14 \text {, } \\
71 \%) \text { ) } \\
\text { Replaced Tac and MMF } \\
\text { with pred ( } n=1,7 \%)\end{array}$ & $\begin{array}{l}\text { Died }(n=1, \\
7 \%) \\
\text { Intubation } \\
(n=4,27 \%)\end{array}$ \\
\hline $\begin{array}{l}\text { ZhuL, et al. } \\
\text { [54] }\end{array}$ & $\begin{array}{l}\text { Kidney } \\
\text { Case Series } \\
\mathrm{n}=10\end{array}$ & $\begin{array}{l}45(24- \\
65), 2 \mathrm{f} \\
8 \mathrm{~m}\end{array}$ & $\begin{array}{l}\mathrm{CNI}, \\
\mathrm{MM}, \\
\text { pred }\end{array}$ & & $\begin{array}{l}\text { GGO and/or } \\
\text { consolidation }\end{array}$ & & $\begin{array}{l}\text { Different regimes, } \\
\text { patients on } \mathrm{CNI}, \mathrm{MMF} \text {, } \\
\text { pred }\end{array}$ & $\begin{array}{l}\text { Died }(n=1, \\
10 \%)\end{array}$ \\
\hline $\begin{array}{l}\text { Fontana F, } \\
\text { et al. [12] }\end{array}$ & $\begin{array}{l}\text { Kidney, } \\
2005\end{array}$ & $61, \mathrm{~m}$ & $\begin{array}{l}\text { CyA } \\
\text { MTP }\end{array}$ & Fever & $\begin{array}{l}38 \\
\mathrm{SpO}_{2} 97 \% \\
\text { CRP } 41 \\
\text { GGO bilat. }\end{array}$ & IIA--> IIB & $\begin{array}{l}\text { CyA 50\% reduced } \\
\text { HCQ } \\
\text { MTP increased } \\
\text { Tocilizumab } \\
\text { IVIG } \\
\text { Meropenem }\end{array}$ & $\begin{array}{l}\text { Survived, hos- } \\
\text { pitalization } 22 \\
\text { days }\end{array}$ \\
\hline $\begin{array}{l}\text { Kates O, et } \\
\text { al. [48] }\end{array}$ & $\begin{array}{l}\text { Kidney, } \\
2000\end{array}$ & $54, \mathrm{~m}$ & $\begin{array}{l}\text { Tac } \\
\text { MMF }\end{array}$ & $\begin{array}{l}\text { Fatigue } \\
\text { Dry cough } \\
\text { Dyspnea } \\
\text { Nausea } \\
\text { Vomiting } \\
\text { Diarrhea }\end{array}$ & $\begin{array}{l}38 \\
\mathrm{SpO}_{2} 93 \% \\
\mathrm{CRP} \text { unknown } \\
\text { CXR multifocal } \\
\text { infiltrates }\end{array}$ & IIB & $\begin{array}{l}\text { MMF discontinued } \\
\text { Tac reduced } \\
\text { Pred } 10 \mathrm{mg} \text { started } \\
\text { Ceftriaxon } \\
\text { Azithromycin } \\
\text { HCQ }\end{array}$ & $\begin{array}{l}\text { survived, hos- } \\
\text { pitalization } 16 \\
\text { days }\end{array}$ \\
\hline $\begin{array}{l}\text { Arpali E, et } \\
\text { al. [55] }\end{array}$ & $\begin{array}{l}\text { Kidney } \\
2020\end{array}$ & $28, f$ & $\begin{array}{l}\text { Tac } \\
\text { MMF } \\
\text { Pred }\end{array}$ & Fever & $\begin{array}{l}38 \\
\mathrm{SpO}_{2} \text { unknown } \\
\text { CRP } 4.5 \\
\text { CXR normal }\end{array}$ & I & $\begin{array}{l}\text { immunosuppression } \\
\text { unchanged }\end{array}$ & $\begin{array}{l}\text { survived, hos- } \\
\text { pitalization } 1 \\
\text { day }\end{array}$ \\
\hline $\begin{array}{l}\text { Zhong Z, et } \\
\text { al. [56] }\end{array}$ & Kidney, & $48, m$ & $\begin{array}{l}\text { Tac } \\
\text { MMF }\end{array}$ & $\begin{array}{l}\text { cough } \\
\text { muscle aches } \\
\text { fatigue } \\
\text { chest tightness }\end{array}$ & $\begin{array}{l}37.8 \\
31 \mathrm{mg} / \mathrm{L} \\
\text { GGO }\end{array}$ & IIA & $\begin{array}{l}\text { Tac unchanged } \\
\text { MMF discontinued } \\
\text { oseltamivir } \\
\text { abidol } \\
\text { moxifloxacin } \\
\text { rh-IFN } \\
\text { MMP } \\
\text { IVIG }\end{array}$ & $\begin{array}{l}\text { survived, hos- } \\
\text { pitalization } 34 \\
\text { days }\end{array}$ \\
\hline
\end{tabular}




\begin{tabular}{|c|c|c|c|c|c|c|c|c|}
\hline $\begin{array}{l}\text { Qin J et al. } \\
\text { [57] }\end{array}$ & $\begin{array}{l}\text { Liver, } \\
2020\end{array}$ & $37, \mathrm{~m}$ & $\begin{array}{l}\text { Tac } \\
\text { Pred }\end{array}$ & unknown & $\begin{array}{l}\text { Temp, } \mathrm{SpO}_{2} \\
\text { and } \mathrm{CRP} \text { un- } \\
\text { known } \\
\text { GGO }\end{array}$ & IIB & $\begin{array}{l}\text { Tac and Pred main- } \\
\text { tained, gradually titrat- } \\
\text { ed to lower doses } \\
\text { HFOT } \\
\text { Oseltamivir } \\
\text { rh-GCSF } \\
\text { IVIG }\end{array}$ & $\begin{array}{l}\text { survived, hos- } \\
\text { pitalization } \\
2 \text { months } \\
\text { (including liver } \\
\text { transplanta- } \\
\text { tion) }\end{array}$ \\
\hline $\begin{array}{l}\text { Lagana SM, } \\
\text { et al. [58] }\end{array}$ & $\begin{array}{l}\text { Liver, } \\
2020\end{array}$ & $0.5, f$ & & $\begin{array}{l}\text { Fever } \\
\text { Dyspnea } \\
\text { Diarrhea }\end{array}$ & $\begin{array}{l}\text { "fever" } \\
\text { CXR bilat. infil- } \\
\text { trates }\end{array}$ & IIA & $\begin{array}{l}\text { CPAP } \\
\text { HCQ } \\
\text { Pred tapering } \\
\text { MMF stopped }\end{array}$ & alive \\
\hline $\begin{array}{l}\text { Huang JF, } \\
\text { et al. [59] }\end{array}$ & $\begin{array}{l}\text { Liver, } \\
2017\end{array}$ & $59, m$ & $\begin{array}{l}\text { Tac } \\
\text { MMF }\end{array}$ & $\begin{array}{l}\text { Fever } \\
\text { Cough } \\
\text { Chills } \\
\text { Fatigue } \\
\text { Diarrhea }\end{array}$ & $\begin{array}{l}40.0 \\
\mathrm{SpO}_{2} \text { normal } \\
\text { CRP } 35.1 \\
\text { GGO }\end{array}$ & $\begin{array}{l}\|A-->\| B \\
-->I I I\end{array}$ & $\begin{array}{l}\text { pip/taz } \\
\text { lopinavir/ritonavir } \\
\text { alpha-IFN (nebul.) } \\
\text { Tac \& MMF reduced } \\
\text { (50\%) (possible drug- } \\
\text { drug interactions with } \\
\text { lopinavir/ritonavir) }\end{array}$ & $\begin{array}{l}\text { day 4: IIB, } \\
\text { nasal oxygen- } \\
\text { ation, stan- } \\
\text { dard methyl- } \\
\text { prednisolone } \\
\text { day 9: invasive } \\
\text { ventilation } \\
\text { day 12: PTx + } \\
\text { PE, drainage } \\
\text { day 15: ECMO } \\
\text { Kidney failure } \\
\text { day 45: died }\end{array}$ \\
\hline $\begin{array}{l}\text { Kates O, et } \\
\text { al. [48] }\end{array}$ & $\begin{array}{l}\text { Liver } \\
2001\end{array}$ & $67, \mathrm{~m}$ & CyA & $\begin{array}{l}\text { Fatigue } \\
\text { Confusion } \\
\text { Dry cough } \\
\text { Diarrhea }\end{array}$ & $\begin{array}{l}\text { Temp, } \mathrm{SpO}_{2} \\
\text { and } \mathrm{CRP} \text { un- } \\
\text { known } \\
\text { CXR normal }\end{array}$ & IIB & CyA continued & $\begin{array}{l}\text { survived, hos- } \\
\text { pitalization } 12 \\
\text { days }\end{array}$ \\
\hline $\begin{array}{l}\text { Zhong Z, et } \\
\text { al. [56] }\end{array}$ & Liver & $37, \mathrm{~m}$ & $\begin{array}{l}\text { Tac } \\
\text { MTP }\end{array}$ & unknown & $\begin{array}{l}38.6 \\
93 \% \\
\text { CRP unknown } \\
\text { GGO }\end{array}$ & IIA & $\begin{array}{l}\text { Tac discontinued } \\
\text { MTP }\end{array}$ & $\begin{array}{l}\text { survived } \\
\text { hospitalization } \\
\text { duration un- } \\
\text { known }\end{array}$ \\
\hline $\begin{array}{l}\text { Steinack C, } \\
\text { et al. [9] }\end{array}$ & $\begin{array}{l}\text { Lung, } \\
2019 \\
\text { (bilat.) }\end{array}$ & $55, f$ & $\begin{array}{l}\text { Tac } \\
\text { MMF } \\
\text { Pred }\end{array}$ & $\begin{array}{l}\text { Nausea } \\
\text { Vomiting } \\
\text { Diarrhea } \\
\text { Dry cough } \\
\text { Rhinorrhea }\end{array}$ & $\begin{array}{l}38.9 \\
96 \% \\
77 \mathrm{mg} / \mathrm{L} \\
3 \text { nodular le- } \\
\text { sions }\end{array}$ & IIA & piperacillin/tazobactam & $\begin{array}{l}\text { survived } \\
\text { hospitalization } \\
12 \text { days }\end{array}$ \\
\hline $\begin{array}{l}\text { Aigner C, et } \\
\text { al. [60] }\end{array}$ & $\begin{array}{l}\text { Lung } \\
\text { (bilat.) } \\
2019\end{array}$ & $59, f$ & $\begin{array}{l}\text { Tac } \\
\text { Pred }\end{array}$ & Asymptomatic & $\begin{array}{l}\text { Afebrile } \\
\text { Hypoxemia } \\
\left(\mathrm{pO}_{2} 55\right. \\
\mathrm{mmHg}) \\
\\
\text { GGO }\end{array}$ & IIB & $\begin{array}{l}\text { Meropenem } \\
\text { Tac and Pred un- } \\
\text { changed }\end{array}$ & $\begin{array}{l}\text { survived } \\
\text { hospitalized } 21 \\
\text { days }\end{array}$ \\
\hline
\end{tabular}


Citation: Hage R, Steinack C, Schuurmans MM (2020) Clinical Aspects of COVID-19 in Patients with Solid Organ Transplantation: A Systematic Review. Res Rev Infect Dis 3(2):102-114

\begin{tabular}{|c|c|c|c|c|c|c|c|c|}
\hline $\begin{array}{l}\text { Shigemura } \\
\mathrm{N}, \text { et al. } \\
{[61]}\end{array}$ & $\begin{array}{l}\text { Lung } \\
\text { (bilat.) } \\
2020\end{array}$ & $\begin{array}{l}\text { Elderly, } \\
\mathrm{m}\end{array}$ & $\begin{array}{l}\text { Tac } \\
\text { Pred }\end{array}$ & Fever & $\begin{array}{l}38.1 \\
90 \% \\
\text { GGO }\end{array}$ & $\| \mathrm{II}-->|I|$ & $\begin{array}{l}\text { Tac and Pred continued } \\
\text { MMF withheld imme- } \\
\text { diately } \\
\text { remdesivir }\end{array}$ & $\begin{array}{l}\text { intubation } \\
\text { died, } 11 \text { days } \\
\text { posttransplant }\end{array}$ \\
\hline $\begin{array}{l}\text { Shigemura } \\
N \text {, et al. } \\
{[61]}\end{array}$ & $\begin{array}{l}\text { Lung } \\
\text { (unilat.) } \\
2020\end{array}$ & $\begin{array}{l}\text { Elderly, } \\
\mathrm{m}\end{array}$ & $\begin{array}{l}\text { Infor- } \\
\text { mation } \\
\text { pending }\end{array}$ & $\begin{array}{l}\text { Severe abdominal } \\
\text { pain, watery stool }\end{array}$ & $\begin{array}{l}\text { Afebrile } \\
\text { GGO in native } \\
\text { lung, no GGO } \\
\text { in donor lung }\end{array}$ & IIB & remdesivir & $\begin{array}{l}\text { clinically sta- } \\
\text { ble, with nasal } \\
\text { cannula with } \\
\text { 3LO2/min. } \\
\text { (follow-up } \\
\text { awaited) }\end{array}$ \\
\hline $\begin{array}{l}\text { Kates O, et } \\
\text { al. [48] }\end{array}$ & $\begin{array}{l}\text { Lung } \\
\text { (bilat) } \\
2000\end{array}$ & $53, \mathrm{f}$ & $\begin{array}{l}\text { CyA } \\
\text { Aza } \\
\text { Pred }\end{array}$ & $\begin{array}{l}\text { Fatigue } \\
\text { Dry cough } \\
\text { Dyspnea }\end{array}$ & $\begin{array}{l}\text { Temp, } \mathrm{SpO}_{2} \\
\text { and } \mathrm{CRP} \text { un- } \\
\text { known }\end{array}$ & I & $\begin{array}{l}\text { none, immunosuppres- } \\
\text { sive therapy continued }\end{array}$ & $\begin{array}{l}\text { survived } \\
\text { no hospitaliza- } \\
\text { tion }\end{array}$ \\
\hline
\end{tabular}

Abbreviations: $\mathrm{ATG}=$ antithymocyte globulin (thymoglobulin); $\mathrm{Aza}=$ azathioprine; bela $=$ belatacept; bilat. = bilateral; $\mathrm{CRP}=\mathrm{C}$-reactive protein; $\mathrm{CT}$ chest $=$ computed tomography of the chest; $\mathrm{CXR}=$ chest $\mathrm{X}$-ray; $\mathrm{CyA}=$ cyclosporin $\mathrm{A} ; \mathrm{ECMO}=$ extracorporeal membrane oxygenation; everol = everolimus; $\mathrm{GGO}=$ ground-glass opacity; HFOT = high flow oxygen therapy; $\mathrm{HCQ}=$ hydroxochloroquine; inh. = inhalation; IST = immunosuppressive therapy; iv = intravenous; IVIG = intravenous immunoglobulin G; leflu = leflunomide; Mes = mesalamine; $\mathrm{MMF}=$ mycophenolate mofetil; $\mathrm{MTP}=$ methylprednisolone; $\mathrm{MV}=$ mechanical ventilation; NIV = non-invasive ventilation; po = per os; Pred = Prednisone; Ptx = pneumothorax; PE = pleural effusion; rh-IFN $\alpha=$ recombinant human interferon alpha; rh-GCSF = recombinant human granulocyte colony-stimulating factor; Tac = tacrolimus, unilat. $=$ unilateral

pain). Muscle aches and rhinorrhea have also been reported. Most, but not all, patients had fever. Oxygen saturation and the level of the CRP have not been reported in all studies (Table 1). In most patients' chest CT showed bilateral groundglass opacities (GGO) (Table 1). Severity staging was made according to Siddiqi [1]. Stage I represented mild, early SARSCoV-2 infection, without pulmonary involvement or hypoxia. In stage II (moderate) there is pulmonary involvement without (Ila) and with (IIb) hypoxia. These patients generally are hospitalized. Stage III is the severe stage with systemic hyperinflammation (cytokine storm), including systemic organ involvement with shock, vasoplegia, respiratory failure and cardiopulmonary collapse. The different treatments and patient outcome are summarized in Table 1. All but 5 patients survived.

The two patients who underwent heart transplantation survived. They were both on tacrolimus and mycophenolate mofetil (MMF) maintenance immunosuppression, in one of them tacrolimus and MMF were discontinued after the diagnosis of COVID-19. One patient underwent both a heartand kidney transplantation, and continued tacrolimus but discontinued MMF, while prednisolone was continued unchanged. He also survived the SARS-CoV-2 infection. There are 34 patients ( 9 case reports and 2 case series) on patients with COVID-19 after renal transplantation, most of them continued tacrolimus. Three patients did not survive COVID-19. Three patients with a liver transplantation, one of them was a 6-months-old girl, another was a 59-year-old patient, who died after a hospitalization of 45 days. For the two adult patients immunosuppression was reduced by lowering the tacrolimus doses. Four patients with a lung transplantation developed COVID-19, one died and in one patient a definitive outcome has not been reported yet. Three of them were on tacrolimus therapy, and this treatment remained unchanged after the COVID-19 diagnosis. The patient who did not survive the infection, developed a stage III COVID-19 disease (see details in Table 1).

\section{Discussion}

During the current SARS-CoV-2 pandemic, affecting tens of millions of individuals worldwide, only a limited number of SOT recipients have been reported in case reports and case series. Between March 16th and May 1st, 2020, only 49 SOT recipients have been described in literature. Most of these patients survived, and had a fairly mild disease course. It may seem surprising, that the life-threatening, highly contagious SARS-CoV-2, did not affect the large majority of the SOT patients, who are on chronic immunosuppression. Compared to the millions of people with COVID-19 worldwide, data on COVID-19 patients with SOT are relatively scarce. Even in the heavily infected Lombardy region (Italy), only three of 111 long-term liver transplant survivors died within 3-12 days following severe COVID-19 [2]. All of these were male, older than 65-years, receiving antihypertensive drugs, overweight $\left(\mathrm{BMI}>28 \mathrm{~kg} / \mathrm{m}^{2}\right)$, with hyperlipidemia, and diabetes [2]. Two of these patients were on cyclosporine treatment, the other one on tacrolimus. By contrast, in this Italian liver transplantation center, 3 of the 40 recently transplanted patients were tested SARS-CoV-2 positive and were experiencing an uneventful course of disease [2]. This is in sharp contrast with the many ascertained SARS-CoV-2 infections in the general population of the Lombardy region, with 7199 virus-related deaths as of March 31, 2020 [3].

Even more surprising is the fact that SOT recipients, in whom a high prevalence of posttransplant comorbidities due to immunosuppression is known, are relatively underrepresented in COVID-19 patient cohorts. One of the COVID-19 risk factors is diabetes mellitus, which is prevalent in $20-40 \%$ of SOT recipients [4]. 


\section{Incidence of viral infections in SOT patients}

Although the above mentioned CoV species 229E, OC43, NL63 and HKU1 generally are not associated with severe disease, this is not the case for immunosuppressed patients. In lung transplant recipients, survival after lung transplantation is not yet as good as that after other solid organ transplants. In these patients, 5 years post transplantation, chronic lung allograft dysfunction (CLAD) develops in about $50 \%$ and has a major impact on post-transplant survival [3]. One study including 98 patients who underwent a lung transplantation, showed that the CoV species were the second largest group of CARVs (19.2\%) in the first year after lung transplantation. Besides, this study showed that CoV in particular was associated with increased risk for CLAD development [5].

In other respiratory viral infections, such as influenza, SOT patients experience prolonged clinical disease, with the risk of progression of the infection to the lower respiratory tract and increased mortality when compared to the immunocompetent population [6]. A multicenter cohort study, with 559 patients, of which 56 were immunosuppressed (including 18 SOT recipients) were prospectively characterized, studying the clinical manifestations and outcomes of confirmedinfluenza A 2009 (H1N1) virus infection. Although clinical symptoms at diagnosis were similar in both groups, immunosuppressed patients with pandemic influenza had bacterial co-infections more frequently $(17.9 \%$ vs. $6.4 \%, p=0.02)$, specifically Gram-negative bacilli and Staphylococcus aureus infections. Mortality was higher in immunosuppressed patients $(7.1 \%$ vs. $1.8 \%, p<0.05)$ [6]. Another study of hospitalized immunosuppressed patients with seasonal influenza reported that one-half of the patients had a pneumonia and one-third of patients were admitted to the ICU, with a $10 \%$ mortality rate [7].

Based on the preliminary data available for COVID-19 in SOT there seems to be a decreased morbidity and mortality in case of infection with SARS-CoV-2.

One explanation may be the potential protective effect of the immune suppression in SOT patients. As has been mentioned above, in the clinical manifestations of COVID-19 three stages of severity (according to Siddiqi) can be seen [1]. In the first stage, early in COVID-19, there is a high viral load with only mild constitutional symptoms. In the second stage, the viral load decreases, but there is an increasing host inflammatory response. This leads to dyspnea with moderate to severe hypoxia, with low or normal procalcitonin. Stage III is the hyperinflammation phase, in which most patients no longer have detectable virus but show an extreme host inflammatory response, leading to acute respiratory distress syndrome (ARDS), systemic inflammatory response syndrome (SIRS)/ shock, cardiac failure and elevated inflammatory markers. In this stage, the immune system is overreacting with an overshooting inflammatory response, also called a cytokine storm. In SOT patients, stage III is extremely rare. A protective effect of immunosuppressive drugs, especially by the calcineurin inhibitors, might play a role in preventing this stage, as was observed in SARS-CoV-1 infections [8].

Secondly, as has been illustrated by Steinack, et al., SOT patients can present with atypical symptoms, therefore the COVID-19 diagnosis may not be considered, especially when symptoms are both mild and atypical [9]. This observation could be important for the detection of COVID-19 in SOT recipients since at the early phase of the pandemic in many centers only symptomatic patients were tested, and therefore probably the number of SARS-CoV-2 infections has been underestimated.

Another explanation may be the prudent behavior of the SOT patients, including minimizing social contacts, personal hygiene, etc. This has also been observed in the Italian cystic fibrosis (CF-) population [10], in which ten patients with cystic fibrosis out of 42161 people in the region known to be infected with SARS-CoV-2, all were infected by family members. Although a comparable situation has also been observed in CF patients in other European countries, other factors, such as long-term use of prophylactic or immunomodulatory antibiotics, might be a protective factor and lead to reduced symptoms despite infection [10].

Nevertheless, a certain case-fatality bias cannot be excluded, as only symptomatic patients were tested, due to scarcity of both test material and health care personnel in the acute phase of the COVID-19 pandemic, with an overwhelming number of patients presenting in a short period of time. Further studies need to clarify the above-mentioned hypotheses.

\section{Clinical manifestations of SARS-CoV-2 infection in SOT patients}

In COVID-19, the classical triade is fever, fatigue and dry cough, which were also the most common clinical features of the COVID-19 patients in Wuhan (China). However, the immunocompromised status of SOT recipients can be associated with more atypical symptoms with gastrointestinal complaints and can be easily overlooked and not recognized as symptomatic COVID-19. In a study with 1141 immunocompetent adults, 183 patients (16\%) presented with gastrointestinal symptoms, the most common symptom was loss of appetite, followed by nausea and vomiting [11]. Diarrhea and abdominal pain were the presenting symptom in $37 \%$ and $25 \%$ of patients, respectively, in another study [12]. When infecting human cells, SARS-CoV-2 uses the human cells expressing angiotensin converting enzyme 2 (ACE2) as an entry receptor. The cells expressing ACE2 are not only expressed in the upper and lower airways, but also in the gastro-intestinal tract, and as such can infect the ACE2 expressing enterocytes. However, the mechanism and presentation of gastrointestinal symptoms in immunocompetent in comparison to immunosuppressed (SOT) patients could be different. Along with the known routes of transmission, alternative routes of transmission are suspected. Interestingly, there is increasing evidence showing that coronaviruses gain access to the CNS via a synapse-connected route, whereas a hematogenous or lymphatic route is very unlikely [13]. By entering the CNS, also the medullary cardiorespiratory center from the mechanoreceptors and chemoreceptors in the lung and the lower airways can be reached, contributing to the respiratory failure by a neurological mechanism.Acute presentations of the neu- 
roinvasive effects of SARS-CoV-2 include headache, nausea and vomiting. In SARS, the SARS-CoV has been demonstrated in the brains from both patients and experimental animals, where the brainstem was heavily infected $[13,14]$.

Another finding in most of the case reports and case series with COVID-19 patients in SOT recipients, is the milder ('early infection', stage I) or moderate ("pulmonary phase", stage II) stage of disease observed, whereas severe COVID-19 ("hyperinflammation" or "cytokine storm", stage III) was extremely rarely described [1]. This was even observed in patients with significant lymphopenia, elevated inflammatory markers (CRP, IL-6), LDH, D-dimer and troponin I, all of which were associated with increased disease severity and poorer outcomes in prior COVID-19 studies of mainly immunocompetent patients [15].

One or more pathophysiological responses to SARS-CoV-2 and COVID-19 could be altered by immunosuppression in SOT patients, although the exact mechanism of this disease modifying phenomenon and its typical presentation, incidence and severity urgently needs to be investigated in further studies. One study reported more severe outcomes ( $18 \%$ mortality, $\mathrm{n}=16 / 90$ ) in SOT recipients (of whom 47 were kidney recipients, 17 lung, 13 liver, 9 heart and 5 dual-organ recipients), but this could probably be attributed to limited testing, leading to non-detection of mild and asymptomatic cases [16].

\section{Current "standard" treatment of COVID-19, pos- sible candidate compounds and interaction po- tential in SOT recipients?}

In the absence of a generally accepted effective pharmacological treatment for COVID-19, many existing treatments are currently being investigated. Until now, the optimal medical management (both in the immunocompetent as in the immune suppressed patients) is unknown. Some pharmacological interventions have shown promising effects in certain patients, but no single medication or medication combination has emerged as standard of care yet.

Remdesivir: This drug was used in the Ebola outbreak, and also showed activity against SARS-CoV-1 and MERS-CoV. It had shown effectiveness against SARS-CoV-2 in animal and in vitro studies. Wang et al. published the first randomized, double-blind, placebo-controlled trial of remdesivir for treating severe COVID-19 [17]. In this study, in which 158 patients admitted to the hospital for severe COVID-19 received remdesivir and 79 placebo, remdesivir was not associated with statistically significant clinical benefits [17]. The hazard of 28-day clinical improvement for 158 patients with remdesivir was only 1.2 times $(95 \% \mathrm{Cl} 0.9$ to 1.8$)$ the hazard of placebo treatment and the 28-day mortality in both these groups did not differ. Glaus et al. suggested that these disappointing findings could be explained by the fact that remdesivir inhibits the coronavirus early in the life cycle according to in vitro and animal studies, and remdesivir might thus require initiation before the peak viral replication [18]. Also Wang et al. reported a stronger clinical effect when remdesivir treatment was started within 10 days of symptom onset compared to those who started after this time [17]. However, as there were not many alternatives, remdesivir has been given to many COVID-19 patients. Moreover, a confounding factor might be that in nearly $20 \%$ of patients in this trial, remdesivir was combined with lopinavir/ritonavir. Any effects influencing clinical improvement or mortality of this combination cannot be fully excluded. Remdesivir's metabolism is likely mediated by hydrolase activity, and although it is a substrate for cytochrome P450 (cyp) 3A4 in vitro, a clinically important CYP3A4 inhibition is not to be expected [19].

Chloroquine/hydroxychloroquine: In the early phase of the COVID-19 pandemic, chloroquine (CQ) and hydroxychloroquine ( $\mathrm{HCQ}$ ) have been proposed as treatment or prevention of COVID-19, since in vitro data show inhibition of the SARS-CoV-2 by increasing the $\mathrm{pH}$ of intracellular lysosomes and endosomes, hampering the fusion of the viral membrane. In addition, $(\mathrm{H}) \mathrm{CQ}$ has been shown to alter the glycosylation of ACE2, which is used by the virus to infect the host cells. Both $\mathrm{CQ}$ and $\mathrm{HCQ}$ block the transport and subsequent release of the viral genome [20]. CQ and HCQ are converted to active metabolites by cytochrome $\mathrm{P} 450$ enzymes including CYP3A4 [19]. It is noteworthy that CQ and HCQ are associated with QTc prolongation, which can be an added risk in SOT patients since CNIs (tacrolimus and cyclosporin) and mTOR inhibitors can also prolong the QT-interval. Moreover, these patients frequently are on maintenance therapy with macrolides such as azithromycin and sometimes antifungals such as itraconazole. The concurrent use of two or three drugs that cause QT interval prolongation may result in additive effects and increase the risk of ventricular arrhythmias including Torsade de Pointes and even sudden death [21]. In patients on CNIs and mammalian target of rapamycin inhibitors (mTORi), receiving therapy with $\mathrm{CQ}$ or $\mathrm{HCQ}$, at least electrocardiography before and during therapy should be performed. Ideally continuous cardiac monitoring should be performed especially when multiple QT interval prolonging drugs are involved that cannot be paused or stopped. Therefore, $\mathrm{CQ}$ and $\mathrm{HCQ}$ should be prescribed with great caution and close monitoring of blood concentrations of the immunosuppressive therapy should be performed. Patients reporting symptoms like dizziness, lightheadedness, palpitation, irregular heart rhythm, shortness of breath or syncope should receive urgent medical attention, to exclude cardiac arrhythmia. Many of these symptoms could be falsely attributed to COVID-19 itself instead of considering them potential cardiac adverse events of the introduced medication. One should bear in mind that both $\mathrm{CQ}$ and HCQ have long elimination half-lives of approximately 40-60 days.

However, having initially been a controversial anti-COVID-19 treatment, several studies now have shown that treatment of COVID-19 with CQ or HCQ is without benefit $[22,23]$.

As many patients, including SOT recipients, have received this treatment, we have mentioned $(\mathrm{H}) \mathrm{CQ}$ in this review.

Lopinavir/ritonavir: One of the main antiviral drugs used in the initial phase of the pandemic to treat COVID-19 is the antiretroviral HIV dual protease inhibitor lopinavir-ritonavir. Ritonavir increases the plasma half-life of lopinavir via inhi- 
bition of CYP3A metabolism, and is a strong CYP3A4 inhibitor, increasing serum levels of CYP3A4 substrates. This drug showed activity against SARS-CoV, when added to ribavirin and steroids. However, in patients with SARS-CoV-2 infections in the early phase of the pandemic, the effectiveness of this combination could not be demonstrated in a study of 199 hospitalized patients with severe COVID-19, showing no improvement above standard care [24].

Ribavirin: In patients with SOT ribavirin has been used to treat infections with RSV, PIV and MPV, and has also been used in high doses in combination with corticosteroids or interferon to treat for SARS-CoV and MERS-CoV. In patients with SARS-CoV-2 it has been administered intrials as monotherapy or in combination with other drugs. It has the advantage of having a broad antiviral activity, being widely available and creating relatively low costs. Currently ribavirin has not a prominent place in most treatment protocols, and a recent larger retrospective study did not show an improved viral clearance for SARS-CoV-2, and also did not improve the mortality rate in COVID-19 [25]. It is noteworthy that ribavirin may lead to toxicity problems due to drug interaction when COVID-19 patients with SOT develop secondary mycotic infections and are treated with amphotericin B.

Tocilizumab: Tocilizumab is a monoclonal antibody directed toward the IL-6 receptor, which licensed for the treatment of rheumatoid arthritis in adults and may be also a potential therapy to treat patients with the severe COVID-19 stage III disease. These patients are characterized by hyperinflammation, in which interleukin (IL-)6 appears to play an important role: IL- 6 concentrations are elevated in this stage of COVID-19. High levels of IL-6 can suppress CYP enzyme functions, so that a treatment with tocilizumab, if effective, may lead to a better CYP enzyme activity, thus potentially affecting all drugs with CYP metabolism $[21,26]$.

\section{COVID-19 treatments and interactions with the immunosuppressive therapy}

Besides being effective against the virus or its disease manifestations, the medication used to treat COVID-19 in SOT recipients needs to be evaluated for interactions with preexisting drugs in these polymedicated patients. The drugs that merit attention in this context are mentioned in Table 2. This topic can be even more complex when the SOT patients with COVID-19 are in the ICU setting because organ dysfunction, lower serum albumin, high volume of distribution and a strong inflammation need to be taken into account. They are frequently dependent on vasopressors. All these factors can change the distribution, metabolism and pharmacokinetics of the therapeutic antiviral drugs and/or the immunosuppressive drugs, having a narrow therapeutic index.

The CYP3A enzyme system is responsible for the metabolism of many drugs, including the immunosuppressive drugs, especially the $\mathrm{CNI}$ and mTORi. Certain drug substrates inhibit isoforms of the cytochrome P450 enzyme activity, such as many of the drugs used experimentally for COVID-19 are known as strong CYP3A4 inhibitors.

As a substrate for the CYP3A system, tacrolimus levels may increase dramatically with concurrent protease inhibitor treatment. Moreover, tacrolimus can also inhibit the metabolic action of the CYP3A system, thereby even further increasing the levels of protease inhibitors. Dose reductions of $>$ $90 \%$ can be indicated, with a usual requirement of tacrolimus of $0.5-1 \mathrm{mg} /$ week to maintain therapeutic tacrolimus blood concentrations when lopinavir/ritonavir is used [21,27]. As a potent immunosuppressive drug with a narrow therapeutic window, increased tacrolimus levels lead to toxicity as well as immunosuppression-related infections. A problematic drug-drug interaction in a kidney transplant recipient with COVID-19 has been reported with tacrolimus $5 \mathrm{mg}$ b.i.d. combined with lopinavir/ritonavir (and due to diarrhea replaced with darunavir/cobicistat), leading to neuropsychiatric symptoms and a tacrolimus level of $90.5 \mathrm{ng} / \mathrm{mL}$ on the fourth day of treatment [28].

Table 2: Important drug-drug interactions of COVID-19 treatments with immunosuppressive drugs. $(\mathrm{H}) \mathrm{CQ}=($ hydroxy)chloroquine; QTc $=$ corrected QT-interval.

\begin{tabular}{|l|l|l|l|l|l|}
\hline & Remdesivir & (H)CQ & Lopinavir/ritonavir & Ribavirin & Tocilizumab \\
\hline Tacrolimus & $\begin{array}{l}\text { no interaction } \\
\text { expected }\end{array}$ & QTc prolongation & $\begin{array}{l}\text { neuropsychiatric effects in } \\
\text { tacrolimus intoxication reduce } \\
\text { tacrolimus to 0.5-1.0 mg/week }\end{array}$ & $\begin{array}{l}\text { no interaction } \\
\text { expected }\end{array}$ & $\begin{array}{l}\text { unchanged, or increase } \\
\text { tacrolimus with close } \\
\text { monitoring }\end{array}$ \\
\hline Cyclosporin & $\begin{array}{l}\text { no interaction } \\
\text { expected }\end{array}$ & $\begin{array}{l}\text { QTc prolongation } \\
\text { Consider dose } \\
\text { reduction to } 25 \mathrm{mg} \\
\text { every 1-2 days }\end{array}$ & $\begin{array}{l}\text { no interaction } \\
\text { expected }\end{array}$ & $\begin{array}{l}\text { unchanged, or increase } \\
\text { cyclosporin with close } \\
\text { monitoring }\end{array}$ \\
\hline Sirolimus & $\begin{array}{l}\text { no interaction } \\
\text { expected }\end{array}$ & $\begin{array}{l}\text { QTc prolongation } \\
\text { reduce sirolimus, } \\
\text { close monitoring, strong drug- } \\
\text { drug interaction expected with } \\
\text { high sirolimus levels }\end{array}$ & $\begin{array}{l}\text { no interaction } \\
\text { expected }\end{array}$ & $\begin{array}{l}\text { unchanged, or increase } \\
\text { sirolimus with close } \\
\text { monitoring }\end{array}$ \\
\hline Mycophenolate & \begin{tabular}{l} 
generally, discontinue or decrease dosage with close monitoring MMF concentrations \\
\hline Prednisolone
\end{tabular} & $\begin{array}{l}\text { generally, continue or increase if other immunosuppressive drugs are discontinued, no routine monitoring of drug } \\
\text { concentrations }\end{array}$ \\
\hline
\end{tabular}


Neuropsychiatric effects in SOT patients on tacrolimus with COVID-19 can be difficult to interpret. First of all, it can be due to toxic levels of tacrolimus, leading to various neurotoxic side effects, including tremors, headaches, dysarthria, neuropathies, delirium, cognitive impairment, somnolence, seizures and posterior reversible encephalopathy syndrome (PRES). Presentation as PRES can also be more subtle, such as described in a case report with a patient presenting with a bilateral optic neuropathy, but progressing further to mental changes and weakness of the extremities [29].

Secondly, there is also growing evidence of COVID-19 related neuropsychychiatric symptoms. These symptoms can be seen during the acute SARS-CoV-2 infection, but also after weeks, months or maybe longer in recovered patients, and may have been under diagnosed previously [30]. In other viral infections, such as the 2009 influenza (H1N1) pandemic [31], SARS (2003) [32] and MERS (2012) [33], inflammatory disorders of the central nervous system (CNS) have been described, including narcolepsy, seizures, encephalitis, encephalopathy, and Guillain-Barré syndrome. A neuroinvasive component has been demonstrated as a common feature of coronaviruses [13]. It is important to bear these potential adverse outcomes in mind for the coming months as the pandemic evolves further. Currently insufficient data from COVID-19 cases is available to assess these potential sequalae, also due to the limited follow-up time. On the other hand, in therapeutic doses, tacrolimus could have a beneficial effect on COVID-19 outcome, by inhibiting the pro-inflammatory cytokines in the severe stage $[9,34]$.

Cyclosporine A (CSA), the $\mathrm{CNI}$ of second choice in many transplant centers, can also lead to relevant drug-drug interactions in this context. In the literature, only 2 case reports described high concentrations cyclosporine during $\mathrm{CQ}$ therapy $[35,36]$. Any medication combination in a transplant recipient including $\mathrm{CQ}$ or $\mathrm{HCQ}$, should be accompanied by routine pharmacokinetic monitoring due to potentially relevant interactions [19]. Some authors recommend strongly a dose reduction and estimate that the half-life of CSA is prolonged 5- to 20-fold due to interaction with lopinavir/ritonavir, therefore dosing regimens of cyclosporin $25 \mathrm{mg}$ every 1-2 days have been suggested [21].

The dose of the antiproliferative agent mycophenolate mofetil (MMF) is usually intentionally reduced in COVID-19 as part of the treatment strategy in analogy to experience with other respiratory viral infections. Currently no data on important pharmacokinetic interactions concerning MMF with the above described treatment options for COVID-19 are known yet. Some authors recommend discontinuing MMF entirely in case of severe COVID-19 in SOT recipients [21]. This was based on the H1N1 pandemic, where MMF treatment resulted in a reduced immune response in SOT recipients $[37,38]$. If $\mathrm{MMF}$ treatment is continued, close monitoring of trough levels and MMF dosage adjustments are advised [21].

Corticosteroids concentrations are not routinely monitored. The CDC recommended avoiding high-dose corticosteroids in patients with COVID-19, based on interference with virus elimination and possibly prolonged viral replication and shedding, which had been reported in patients with MERS $[39,40]$. Corticosteroid treatment initially was not supported by clinical evidence in the treatment of ARDS in COVID-19 although data from SOT recipients are missing and the maintenance or slightly increased dose of corticosteroid (adrenal insufficiency, stress dose) should be given.

However, as we know now, in severe COVID-19 (Siddiqi phase III), autopsies not only showed the Diffuse Alveolar Damage (DAD) in clinically ARDS patients, but also components with organizing pneumonia (OP) or non-specific interstitial pneumonia (NSIP), which are potentially corticosteroid responsive. Beside the irreversible post-COVID-19 fibrosis (DAD, clinically ARDS) there could be also a reversible, more inflammatory, component (OP, NSIP) that could improve on corticosteroid treatment. However, there is no international consensus on this topic yet. Importantly, before starting corticosteroids in SOT recipients, invasive pulmonary aspergillosis (IPA) should be excluded [41]. Although IPA is a contraindication for corticosteroid treatment, this does not hold true for the COVID-19-associated pulmonary Aspergillosis (CAPA) [42]. In case of CAPA, being a relative but not absolute contraindication for corticosteroid treatment, it is mandatory to treat Aspergillus as soon as corticosteroids are initiated. Beside Aspergillus treatment, bronchoalveolar lavage should exclude positive herpes simplex (HSV) and cytomegalovirus (CMV) infection by PCR. In case of positive HSV and CMV in the lower airways, viral load should be followed-up, and therapy with aciclovir/ganciclovir should be considered. Currently, in most transplant centers, dexamethason is the corticosteroid treatment of choice based on the RECOVERY trial results [43]. In the prospective meta-analysis of September 2020, Sterne, et al. included 7 randomized controlled trials with a total of 1703 included patients, including hospitalized and critically ill COVID-19 patients [44]. In these patients, they compared the effect of corticosteroids to standard care or placebo. There were 222 deaths among the 678 patients randomized to corticosteroids, and 425 deaths among the 1025 patients randomized to usual care or placebo. It was concluded that systemic corticosteroids compared with usual care or placebo, was associated with lower 28-day all-cause mortality [44].

Sirolimus is an inhibitor of the IL-2 receptor, preventing proliferation of T-lymphocytes, and reducing the production of antibodies. It is an alternative to tacrolimus or CSA, for example in patients who develop a decreased renal function on CNI treatment. Although the interaction with lopinavir/ ritonavir can lead to very high levels of sirolimus and thus requires close monitoring, it could also have an antiviral effect that may be beneficial [45]. In MERS-CoV, it showed improvement of the infection in over $60 \%$ of patients. Also, in patients with a severe H1N1 pneumonia with acute respiratory failure sirolimus improved the prognosis significantly [32]. In vitro studies have reported it to effectively block viral protein expression and virion release [45]. However, activity against SARS-CoV-2 is currently unknown, and currently no case reports on sirolimus in SOT patients with COVID-19 have been reported to date. Based on its track-record with encouraging results in other CoV diseases, sirolimus treatment might be an interesting option for clinical trials with COVID-19 in SOT 
recipients.

Summarizing the interactions in SOT patients with COVID-19, tacrolimus, cyclosporine and sirolimus drug levels can be elevated in combination with $\mathrm{CQ} / \mathrm{HCQ}$, and also with lopinavir/ritonavir treatment, and are decreased in combination with tocilizumab, while probably being unchanged in combination with remdesivir and ribavirin. Especially the strong interaction of sirolimus with lopinavir/ritonavir should be considered. For mycophenolate mofetil, no relevant interactions with these potential anti-COVID-19 drugs are to be expected. In many transplant centers, generally MMF is discontinued on initial admission and throughout the course of COVID-19, while tacrolimus and prednisone are continued. Caution and careful clinical and pharmacological monitoring of drug levels in SOT recipients with COVID-19 is mandatory.

\section{Lung transplantation as consequence of COVID-19}

Patients with previously healthy lungs may become lung transplant candidates due to the consequences of end-stage COVID-19 pneumonia. In one case report, two Chinese patients (66-year-old woman and a 70-year-old male) on extracorporeal membrane oxygenation (ECMO) after COVID-pneumonia, underwent a lung transplantation as the only way to save their lives. The long-term results are to be awaited, however, in the resected lungs of both patients, live SARS-CoV-2 could no longer be detected anymore, possibly suggesting a short persistence of virus despite triggering major pathogenetical mechanisms [46].

\section{Conclusion}

Based on the limited research data, no firm conclusions can be made yet concerning the best treatment option for SOT recipients with COVID-19. The current evidence suggests that immunosuppression, especially including the calcineurin inhibitors, improves the outcome of SARS-CoV-2 infection and COVID-19, preventing or suppressing hyperinflammation (cytokine storm) in these patients, thus leading to less severe COVID-19 presentations. Pharmacological treatment options for COVID-19 need to take into account the risks of drug-drug interactions affecting the overall immunosuppression and toxicity. Being on immunosuppressive treatment appears to blunt the inflammatory reaction typically seen in immunocompetent patients with a cytokine storm. Evidence based guidelines are urgently needed.

\section{Author Contributions}

Concept and primary literature search was performed by R.H. and M.M.S. All authors agreed to the submission of the final manuscript version.

\section{References}

1. Siddiqi HK, Mehra MR (2020) COVID-19 illness in native and immunosuppressed states: A clinical-therapeutic staging proposal. J Heart Lung Transplant 39: 405-407.

2. Bhoori S, Rossi RE, Citterio D, et al. (2020) COVID-19 in long-term liver transplant patients: Preliminary experience from an Italian transplant centre in Lombardy. Lancet Gastroenterol Hepatol 5: 532-533.
3. Thabut G, Mal H (2017) Outcomes after lung transplantation. J Thorac Dis 9: 2684-2691.

4. Jenssen T, Hartmann A (2019) Post-transplant diabetes mellitus in patients with solid organ transplants. Nat Rev Endocrinol 15: 172-188.

5. Magnusson J, Westin J, Andersson LM, et al. (2018) Viral respiratory tract infection during the first postoperative year is a risk factor for chronic rejection after lung transplantation. Transplantation Direct 4: e370.

6. Cordero E, Aydillo T, Fariñas MC, et al. (2012) Immunosuppressed patients with pandemic influenza A 2009 (H1N1) virus infection. Eur J Clin Microbiol Infect Dis 31: 547-556.

7. Schnell D, Mayaux J, Bazelaire C de, et al. (2010) Risk factors for pneumonia in immunocompromised patients with influenza. Respir Med 104: 1050-1056.

8. Carbajo-Lozoya J, Müller MA, Kallies S, et al. (2012) Replication of human coronaviruses SARS-CoV, HCoV-NL63 and HCoV-229E is inhibited by the drug FK506. Virus Res 165: 112-117.

9. Steinack C, Hage R, Benden C (2020) SARS-CoV-2 and Norovirus co-infection after lung transplantation. Transplantology 1: 1623.

10. Colombo C, Burgel PR, Gartner S, et al. (2020) Impact of COVID-19 on people with cystic fibrosis. Lancet Respir Med 8: e35-e36.

11. Luo S, Zhang X, Xu H (2020) Don't overlook digestive symptoms in patients with 2019 novel coronavirus disease (COVID-19). Clin Gastroenterol Hepatol 18: 1636-1637.

12. Fontana F, Alfano G, Mori G, et al. (2020) Covid-19 pneumonia in a kidney transplant recipient successfully treated with Tocilizumab and Hydroxychloroquine. Am J Transplant 20: 1902-1906.

13. Li YC, Bai WZ, Hashikawa T (2020) The neuroinvasive potential of SARS-CoV2 may be at least partially responsible for the respiratory failure of COVID-19 patients. J Med Virol 92: 552-555.

14. Lechien JR, Chiesa-Estomba CM, Siati DR de, et al. (2020) Olfactory and gustatory dysfunctions as a clinical presentation of mild-to-moderate forms of the coronavirus disease (COVID-19): A multicenter European study. Eur Arch Otorhinolaryngol 277: 2251-2261.

15. Hsu JJ, Gaynor P, Kamath M, et al. (2020) COVID-19 in a high-risk dual heart and kidney transplant recipient. Am J Transplant 20: 1911-1915.

16. Pereira MR, Mohan S, Cohen DJ, et al. (2020) COVID-19 in solid organ transplant recipients: Initial report from the US epicenter. Am J Transplant 20: 1800-1808.

17. Wang Y, Zhang D, Du G, et al. (2020) Remdesivir in adults with severe COVID-19: A randomised, double-blind, placebo-controlled, multicentre trial. The Lancet 395: 1569-1578.

18. Glaus MJ, Ruden S Von (2020) Remdesivir and COVID-19. The Lancet 396: P952.

19. Mahmoudjafari Z, Alexander M, Roddy J, et al. (2020) American society for transplantation and cellular therapy pharmacy special interest group position statement on pharmacy practice management and clinical management for COVID-19 in hematopoietic cell transplantation and cellular therapy patients in the United States. Biol Blood Marrow Transplant 26: 1043-1049.

20. Liu J, Cao R, Xu M, et al. (2020) Hydroxychloroquine, a less toxic derivative of chloroquine, is effective in inhibiting SARS-CoV-2 infection in vitro. Cell Discov 6: 16. 
21. Elens L, Langman LJ, Hesselink DA, et al. (2020) Pharmacologic treatment of transplant recipients infected with SARS-CoV-2. Ther Drug Monit.

22. Cavalcanti AB, Zampieri FG, Rosa RG, et al. (2020) Hydroxychloroquine with or without azithromycin in mild-to-moderate Covid-19. N Engl J Med.

23. Skipper CP, Pastick KA, Engen NW, et al. (2020) Hydroxychloroquine in nonhospitalized adults with early COVID-19. Ann Intern Med 173: 623-631.

24. Cao B, Wang Y, Wen D, et al. (2020) A trial of Lopinavir-Ritonavir in adults hospitalized with severe Covid-19. N Engl J Med 382: 1787-1799.

25. Tong S, Su Y, Yu Y, et al. (2020) Ribavirin therapy for severe COVID-19: A retrospective cohort study. Int J Antimicrob Agents 56: 106114.

26. Kim S, Östör AJK, Nisar MK (2012) Interleukin-6 and cytochrome-P450, reason for concern? Rheumatology International 32: 2601-2604.

27. Jain AB, Venkataramanan R, Eghtesad B, et al. (2003) Effect of coadministered lopinavir and ritonavir (Kaletra) on tacrolimus blood concentration in liver transplantation patients. Liver Transpl 9: 954-960.

28. Bartiromo M, Borchi B, Botta A, et al. (2020) Threatening drugdrug interaction in a kidney transplant patient with Coronavirus Disease 2019 (COVID-19). Transpl Infect Dis 22: e13286.

29. Kommana SS, Bains U, Fasula V, et al. (2019) A case of tacrolimus-induced posterior reversible encephalopathy syndrome initially presenting as a bilateral optic neuropathy. Case Reports in Ophthalmology 10: 140-144.

30. Troyer EA, Kohn JN, Hong S (2020) Are we facing a crashing wave of neuropsychiatric sequelae of COVID-19? Neuropsychiatric symptoms and potential immunologic mechanisms. Brain, Behavior, and Immunity 87: 34-39.

31. Wu H, Zhuang J, Stone WS, et al. (2014) Symptoms and occurrences of narcolepsy: A retrospective study of 162 patients during a 10-year period in Eastern China. Sleep Med 15: 607-613.

32. Wang CH, Chung FT, Lin SM, et al. (2014) Adjuvant treatment with a mammalian target of rapamycin inhibitor, sirolimus, and steroids improves outcomes in patients with severe H1N1 pneumonia and acute respiratory failure. Crit Care Med 42: 313-321.

33. Kim JE, Heo JH, Kim HO, et al. (2017) Neurological complications during treatment of middle east respiratory syndrome. J Clin Neurol 13: 227-233.

34. Hage R, Steinack C, Benden C, et al. (2020) COVID-19 in patients with solid organ transplantation: A systematic review. Transplantology 1: 1-15.

35. Finielz P, Gendoo Z, Chuet C GJ (1993) Interaction between cyclosporin and chloroquine. Nephron 65: 333.

36. Nampoory MR, Nessim J, Gupta RK, et al. (1992) Drug interaction of chloroquine with ciclosporin. Nephron 62: 108-109.

37. Mulley WR, Visvanathan K, Hurt AC, et al. (2012) Mycophenolate and lower graft function reduce the seroresponse of kidney transplant recipients to pandemic H1N1 vaccination. Kidney Int 82: 212-219.

38. Resende MR, Husain S, Gubbay J, et al. (2013) Low seroconversion after one dose of AS03-adjuvanted $\mathrm{H} 1 \mathrm{~N} 1$ pandemic influenza vaccine in solid-organ transplant recipients. Can J Infect Dis Med Microbiol 24: e7-e11.
39. Zumla A, Perlman S, McNabb SJN, et al. (2015) Middle east respiratory syndrome in the shadow of ebola. Lancet Respir Med 3: 100-102.

40. Arabi YM, Mandourah Y, Al-Hameed F, et al. (2018) Corticosteroid therapy for critically ill patients with middle east respiratory syndrome. Am J Respir Crit Care Med 197: 757-767.

41. Koehler P, Cornely OA, Böttiger BW, et al. (2020) COVID-19 associated pulmonary aspergillosis. Mycoses 63: 528-534.

42. Arastehfar A, Carvalho A, Veerdonk FL van de, et al. (2020) COVID-19 associated pulmonary aspergillosis (CAPA)-from immunology to treatment. J Fungi (Basel) 6: 91.

43. RECOVERY Collaborative Group, Horby P, Lim WS, et al. (2020) Dexamethasone in hospitalized patients with Covid-19 - preliminary report. Engl J Med.

44. Sterne JAC, Murthy S, Diaz JV, et al. (2020) Association between administration of systemic corticosteroids and mortality among critically ill patients with COVID-19: A meta-analysis. JAMA 324: 1330-1341.

45. Dyall J, Gross R, Kindrachuk J, et al. (2017) Middle east respiratory syndrome and severe acute respiratory syndrome: Current therapeutic options and potential targets for novel therapies. Drugs 77: 1935-1966.

46. Han W, Zhu M, Chen J, et al. (2020) Lung Transplantation for elderly patients with end-stage COVID-19 Pneumonia. Ann Surg.

47. Li F, Cai J, Dong N (2020) First cases of COVID-19 in heart transplantation from China. J Heart Lung Transplant 39: 496-497.

48. Kates OS, Fisher CE, Stankiewicz-Karita HC, et al. (2020) Earliest cases of coronavirus disease 2019 (COVID-19) identified in solid organ transplant recipients in the United States. Am J Transplant 20: $1885-1890$.

49. Zhu L, Xu X, Ma K, et al. (2020) Successful recovery of COVID-19 pneumonia in a renal transplant recipient with long-term immunosuppression. Am J Transplant 20: 1859-1863.

50. Guillen E, Pineiro GJ, Revuelta I, et al. (2020) Case report of COVID-19 in a kidney transplant recipient: Does immunosuppression alter the clinical presentation? Am J Transplant 20:1875-1878.

51. Gandolfini I, Delsante M, Fiaccadori E, et al. (2020) COVID-19 in kidney transplant recipients. Am J Transplant 20: 1819-1825.

52. Marx D, Moulin B, Fafi-Kremer S, et al. (2020) First case of COVID-19 in a kidney transplant recipient treated with belatacept. Am J Transplant 20: 1944-1946.

53. Columbia University Kidney Transplant Program (2020) Early description of Coronavirus 2019 disease in kidney transplant recipients in New York. J Am Soc Nephrol 31: 1150-1156.

54. Zhu L, Gong N, Liu B, et al. (2020) Coronavirus Disease 2019 pneumonia in immunosuppressed renal transplant recipients: $A$ Summary of 10 confirmed cases in Wuhan, China. Eur Urol 77: 748-754.

55. Arpali E, Akyollu B, Yelken B, et al. (2020) Case report: A kidney transplant patient with mild COVID-19. Transpl Infect Dis 22: e13296.

56. Zhong Z, Zhang $\mathrm{Q}$, Xia $\mathrm{H}$, et al. (2020) Clinical characteristics and immunosuppressants management of coronavirus disease 2019 in solid organ transplant recipients. Am J Transplant 20: 19161921. 
57. Qin J, Wang H, Qin X, et al. (2020) Perioperative presentation of COVID-19 disease in a liver transplant recipient. Hepatology.

58. Lagana SM, Michele S de, Lee MJ, et al. (2020) COVID-19 associated hepatitis complicating recent living donor liver transplantation. Arch Pathol Lab Med.

59. Huang JF, Zheng KI, George J, et al. (2020) Fatal outcome in a liver transplant recipient with COVID-19. Am J Transplant 20: 1907-1910.
60. Aigner C, Dittmer U, Kamler M, et al. (2020) COVID-19 in a lung transplant recipient. J Heart Lung Transplant 39: 610-611.

61. Shigemura N, Cordova F, Criner G, et al. (2020) Current precautions and future directions in lung transplantation during the COVID-19 pandemic - a single center cohort study. Transplant International 33: 1453-1457.

DOI: $10.36959 / 719 / 576$

Copyright: (C) 2020 Hage R, et al. This is an open-access article distributed under the terms of the Creative Commons Attribution License, which permits unrestricted use, distribution, and reproduction in any medium, provided the original author and source are credited. 